\title{
Radio in the Convergence Era: A Case Study of Bravos Digital Radio
}

\author{
Budhi Widi Astuti ${ }^{1}$, Harliantara ${ }^{2}$ \\ Faculty of Social and Communication Science, Universitas Kristen Satya Wacana, Indonesia ${ }^{1}$ \\ Department of Communication Science, Universitas Dr. Soetomo, Surabaya, Indonesia ${ }^{2}$ \\ \{budhi.astuti@uksw.edu¹, harliantara@unitomo.ac.id ${ }^{2}$ \}
}

\begin{abstract}
The political reformation in Indonesia in 1998 has resulted in extraordinary changes in the broadcasting system in Indonesia. The radio broadcasting industry has developed, including the private, public, community and subscription broadcasters. Coupled with the era of the rise of the internet and digital revolution, it results in a variety of significant changes in the radio broadcasting industry. For example, changes in broadcasting technology innovation, broadcasting regulation, globalization, listeners' desires, and etc. At that time, the radio industry in Indonesia was developing and building itself into a media suitable and decent for listeners in the midst of the intense competition with television. When the radio industry was still developing and pushing themselves to exist, they were confronted with the presence of new media and the inevitable digitalization. In this case, the radio industry as a senior media has homework for its management organizations to prepare for these changes. One of the things that must be faced by the radio management is media convergence. It involves the convergence of technology, functions, and the industry structure itself. In Jakarta, there was a radio broadcasting media which strives to exist in the current era of convergence named Bravos Digital Radio Jakarta. In their broadcasting activities, they combined internet technology to broadcast their superior programs. They chose to continue to exist in the current digital era by performing specific strategies determined by their management. This study aims to explain the strategies performed by the management of Bravos Digital Radio in facing the convergence era. This study was done in a qualitative manner with a case study of Bravos Digital Radio which used a strategy to incorporate internet technology into their broadcast activities. Innovation diffusion theory were used to elaborate the case. The theory could help explaining the Bravos Digital Radio management's readiness in facing the digital era and the strategies taken by the radio management. The primary data was obtained through observation, in-depth interviews with the management of Bravos Digital Radio Jakarta, and related literature studies.
\end{abstract}

Keywords: Convergence; Innovation Diffusion; Digital Radio 


\section{Introduction}

The progress of information and communication technology has now become one of the milestones of radio broadcasting in Indonesia. After the political reforms that took place in 1998 that changed the broadcasting system in Indonesia, the current era of information technology has added to the euphoria of press freedom and the growth of the radio broadcasting industry in Indonesia. In the last ten years, radio broadcasting in Indonesia has developed quite well, both in terms of quantity and quality, although there are still issues that have not yet been resolved. For example, the issue of broadcast digitalization which is one of the important issues discussed in the revision of the Broadcasting Law of 2002. Unfortunately, until now digitalization has not yet been discussed, there is no legal umbrella, and it is uncertain when it will begin to be implemented in Indonesia. This condition has caused confusion for radio broadcasting industry players throughout Indonesia. On the one hand, if we want to advance radio broadcasting in Indonesia, we must jointly implement this digitalization and be able to adapt in the global world. Meanwhile, on the other hand, we are not ready to implement it because there are no laws or adequate infrastructure. However, this does not mean that the radio broadcasting industry players only remain silent without making changes or adaptations. Especially now that we live in a digital age, where all things that conventional will gradually be replaced by digital ones. The confusion of the radio broadcasting industry players is overcome by continuing to run conventional broadcasting systems, but also incorporating digital technology that they can reach and apply. Here comes the name of media convergence. In Jakarta, there is a radio broadcasting media which strives to exist in the current era of convergence, named Bravos Digital Radio, the first digital radio in Indonesia. This study aims to explain the strategy of the management of Bravos Digital Radio Jakarta in the convergence era.

\section{a) Media Convergence}

According to the Dictionary of ICT, convergence is the combination of two or more different technologies producing a new technology. For example, fax machines are the product of the convergence of telephone, scanning and printing technologies [1]. Sonia Livingstone noted asking 'what's new for the society about the new media?' compared to 'what are the new media?'. New media is a combination of 3C which stands for Computing and Information Technology (IT), Communications Networks, and Digitized Media and Information Content [2]. Flew presents another $\mathrm{C}$ of this combination, it is Convergence. The digitization and convergent technology show that the boundaries of media platforms are very easy to bypass, that is, easy to share with news makers on television, radio and the web [3]. The development of digital discourse has so far been oriented towards text and images but needs to emphasize compatibility among all types of information and forms of representation available. Sounds and related topics such as "sound" have been marginalized. This is the case with the evolution of digital literacy [4]. But in its current development, digital convergence has the potential to offer many desirable attributes, with easier use, lower costs, and higher potential for monopolistic behavior if the level of digital convergence is greater. Through digital it is possible to integrate a number of the best solutions through a single formation portal in managing digital data systems (text, images, audio and video). Convergence of content management systems brings many benefits to be easy to manage audio and visual content through websites that are accessed through the information portal [5]. 


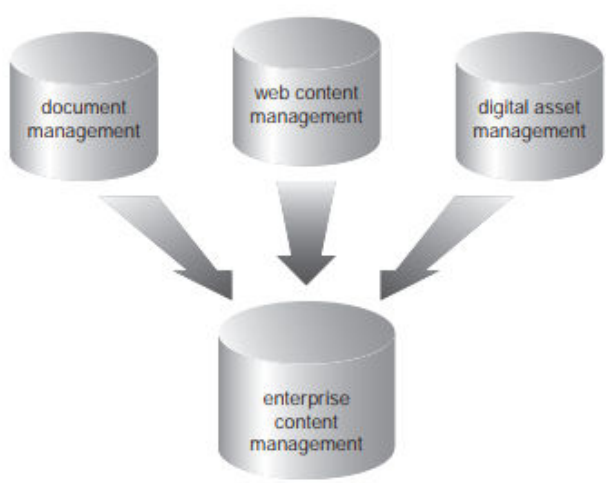

Fig. 1. Convergency System

\section{b) Diffusion of Innovation Theory}

Everett Rogers explains the definition of diffusion as follows: Diffusion is the process by which an innovation is communicated through certain channels over time among members of a social system [6]. Diffusion is a special type of communication focusing on the dissemination of messages containing new ideas. Communication is the process by which participants create and share information with others to achieve the same understanding. This is the novelty of ideas in a message content that is a special character of diffusion, including the degree of uncertainty. The main elements in the diffusion of new ideas are: (1) innovation (2) communicated through certain channels, (3) at a certain time, (4) among members of a social system. Innovation is an idea, practice, or object considered new by both individual and unit adopters.

\section{c) Digital Radio}

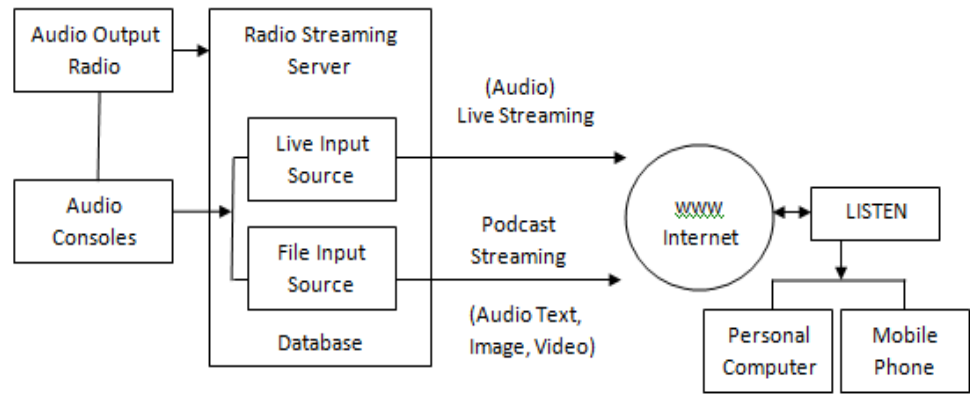

Fig. 2. Digital Radio Broadcast Scheme

Radio broadcasting is a growing medium. Over the last century radio broadcasting has adapted changes in culture and technology to remain popular and distinctive media even though other media continue to grow such as television, cinema, cable services, satellite, music recording, and even the Internet. The broadcasting environment of radio broadcasting has now changed. Digital radio is one of the mass media that has experienced the influence of the development of information and communication technology in the current digital era. It is 
a part of the convergence of media that exists today. This convergence involves radio as a mass media and digital technology. Internet access and communication technology enable message producers and recipients (broadcasters and listeners) to interact through digital access and digital communication tools. For example, listening to radio broadcasts streamed through cellphones and websites [7].

\section{Method}

In researching radio management strategies in the era of convergence, researchers used a qualitative research approach [8] with an explanatory type of research [9]. In the initial stages of this research, the researcher will explain about media convergence, then about radio readiness to face the era of convergence, followed by what strategies are taken by radio management in facing the era of convergence. Thus, the research framework is as follows:

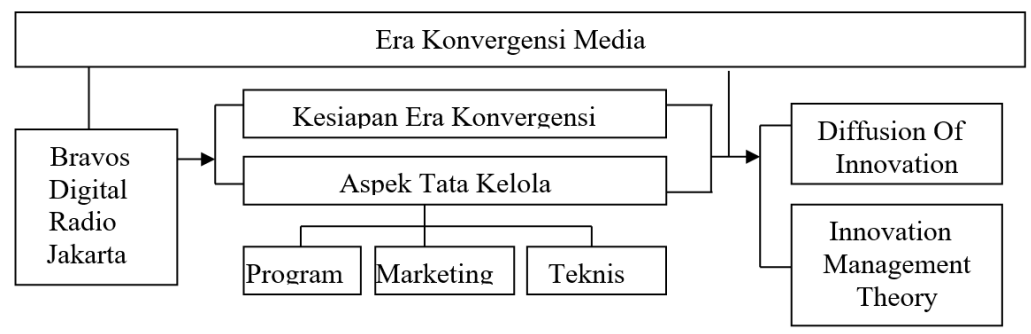

Fig. 3. Research Framework

\section{Result and Discussion}

Based on the governance aspect, Bravos Digital Radio was the first digital radio in Indonesia, located at 6 Batu Ampar 1 Street, Kramat Jati, East Jakarta. The radio, which was under the auspices of PT. Mitra Media Infotek, was present in the midst of the preparation of the broadcasting world to enter the digital era. Bravos Digital Radio responded to the need to listen to radio through the internet, both audio streaming and audio-video streaming. From the management aspect, at the moment, Bravos Digital Radio was led by a Commissioner \& Supervisor, supported by a Station Manager \& PIC of Business and Finance, PIC of Program, Production and News, PIC of Music Director, PIC of Transmitter Engineer, and Marketing Officer. Four of six are the main broadcasters on Bravos Digital Radio. Furthermore, on the program aspect, Bravos Digital Radio was planned to broadcast via AM broadcast frequency in early 2017. However, after submitting a licensing process to obtain radio broadcast frequencies and until the study was conducted, Bravos Digital Radio had not received the desired broadcast license [10]. For these reasons, Bravos Digital Radio decided to continue broadcasting, but did not use the AM broadcast frequency as previously planned but through the digital broadcasting technology such as audio streaming and audio-video streaming.

Next, technically, in broadcasting their programs, Bravos Digital Radio could be accessed through: 1) Website www.bravosradio.com; 2) Facebook account [11]; 3) Youtube.com/BravosRadioIndonesia [12]. In addition, Bravos Digital Radio also had other supporting accounts, for example Twitter [13] and Instagram [14]. 


\subsection{Media Convergence on Bravos Digital Radio}

In Bravos Digital Radio, the obvious form of convergence was the digital radio used for radio broadcasting activities. They combined conventional radio broadcasting systems with television broadcasting systems. They provided a variety of programs for listeners through conventional radio broadcasts, but they could also be enjoyed as when the listeners were watching television. This was because in the radio broadcast process, there were three broadcast cameras recording the course. The entire process of radio broadcast activities that could be heard and seen could be accessed through the website, Facebook account and Youtube account of Bravos Radio Indonesia. In addition to using digital technology for its broadcasting activities, Bravos Digital Radio also utilized various software and hardware to support the broadcasting process. The software used for broadcasting was RadioDJ. It made it easy for the broadcasters to control song playlists and programs remotely. While the hardware used were broadcast cameras, broadcast devices such as audio mixers, camera switchers, computers, headsets and microphones. From the explanation on the software and hardware used by Bravos Digital Radio, it was safe to conclude that they described the form of convergence existed in Bravos Digital Radio. Livingstone stated that what was more important was what's new to the public about new media, than what new media was. Answering this question, the new thing for the public, especially radio listeners, was that they could listen to the radio not only through conventional radio sets or radio devices on cell phones by looking for the desired radio frequency, but also through the internet to access the radio broadcasts.

\subsection{Digital Radio Innovation}

The idea of running digital radio broadcasting was such an innovation in the broadcasting world that must be spread to all team members, through certain channels and at certain times. The process of innovation diffusion involved several important elements. First, innovation. From an economic perspective, digital radio innovation was considered to have cheaper operating costs than the conventional radio. Then, in terms of social, digital radio was considered more prestigious than the conventional radio as a radio was considered to have listeners with a higher level of socioeconomic status and were more educated. It was because listening to digital radio required a computer, laptop or cellular phone with quite high specifications and an internet quota expensive enough to be able to access the digital radio broadcasts. The second attribute of innovation is compatibility. This digital radio innovation was an appropriate and consistent innovation with the condition of the radio broadcasting system in Indonesia which was slowly moving towards digitization. The third attribute of innovation was complexity. The steps taken by the Bravos Digital Radio management to start broadcasting digitally were considered the right decision because the digital broadcast innovations adopted had not been too complex compared to if broadcasting digitalization programs were actually implemented in Indonesia. The fourth attribute of innovation was the ability to test (triability). This digital broadcast innovation had been tested well and successfully. It started by producing broadcast content for broadcast at a certain time (delayed broadcast) and utilizing new media such as Youtube to broadcast their special programs. Then the fifth attribute of innovation is observable. The easier it was for individuals to see the results of an innovation, the more likely they were to adopt. Bravos Digital Radio utilized digital communication technology for broadcasting, including broadcasting content through YouTube, Facebook and websites. 
The second element in the diffusion of innovation was the communication channel. In the context of Bravos Digital Radio, the management conveyed ideas about digital radio broadcasting systems through interpersonal channels considered more effective in shaping and changing the broadcasters' behavior. The broadcasters were given an understanding and briefing about the digital radio broadcasting systems, such as: 1) the concept of digital radio broadcasts they adopted; 2) the software and hardware used in digital radio broadcasts; and 3) the broadcaster basic competencies and skills needed in digital radio broadcasting. The third element was time. The Bravos Digital Radio Commissioner knew that the digital era would replace the conventional era, so he immediately explained to the broadcasters to understand the era of digitalization and how digitalization was developing in a radio station. Once the broadcasters understood what the digital broadcasting was, they would be influenced to accept this digital radio broadcast innovation.

The fourth element was the members in a social system. Bravos Digital Radio was a social system consisting of a collection of interrelated units. The organizational structure of Bravos Digital Radio had not changed from the one designed at the time of submission of AM frequency licensing. For Bravos Digital Radio, this simple organizational structure had more advantages where it facilitated the diffusion process of digital radio innovation better because the communication run more effectively.

\subsection{Execution Strategies of Digital Radio Innovation by Bravos Digital Radio Management}

The current digitalization era had resulted in the radio broadcasting industry having to race to adapt and adopt technology to survive facing competition with other media. Radio as a mass media must adapt so that it was not abandoned by its listeners in addition to the development of new media (online) which was now also beginning to shift the existence of conventional mass media. As stated by Tacchi that in the current era of digital technology and audio, the use of new technologies combined with existing broadcasting technology or techniques is of good potential [15]. Therefore, the management of Bravos Digital Radio implemented the following strategies: First, the governance strategies. The management decided to continue organizing the radio broadcasting activities via the digital online platforms. Second, the audio-video content production strategy. One of the characteristics of radio was imaginative. This concept was called the theater of mind. Bravos Digital Radio produced content digitally and convergent, which combined conventional radio media technology to produce audio content and broadcast cameras to produce video content. Third, the innovative human resource strategies. The management did not change the formation of their organizational structure, but they utilized the existing human resources by strengthening their respective competencies. Fourth, the technical strategy. Bravos Digital Radio produced content digitally and convergent, but the broadcasting system was not yet digital. Fifth, the alternative advertising strategies. As Bravos Digital Radio did not broadcast like the conventional one but through a digital platform, the opportunity to obtain advertisements was also different. However, it did not mean that they would not get revenue from the advertising. It was only the model that was different. 


\section{Conclusion}

The concept of digital radio broadcasts developed on Bravos Digital Radio produced digital and convergent broadcasts using conventional radio broadcast technology and cameras, so as to produce radio broadcasts that could be seen (audio-video content). Bravos Digital Radio broadcast content were shared to the listeners through the website, Youtube and Facebook accounts, both done in live and uploaded, so that the listeners could listen at any time and choose which programs they wanted to listen to. The process of innovation diffusion took place through interpersonal communication channels where there were interactions between the management to the broadcasters in instilling digital concepts and introducing and guiding the broadcasters to operate their broadcasts digitally. The time needed to adopt this digital radio innovation was relatively short for the previous broadcasters were senior broadcasters on the conventional radio. They did not need long time to adapt to new technology. Thus, it could be concluded that the strategies taken by the management to make the diffusion of digital radio innovations successful and brought benefits to Bravos Digital Radio were the governance, audio-video content production, innovative human resource, technical and alternative advertising strategies.

\section{References}

[1] S.M.H. Collin. Dictionary of ICT, $4^{\text {th }}$ ed., London: Bloomsbury Publishing Plc, 2004.

[2] S.M.H. Collin. Dictionary of ICT, $4^{\text {th }}$ ed., London: Bloomsbury Publishing Plc, 2004.

[3] J.I. Erdal. Researching Media Convergence and Crossmedia News Production Mapping the Field, Nordicom Review Vol 28, No. 2, pp. 5161, 2007.

[4] G. Liestol, A. Morrison, T. Rasmussen. Digital Media Revisited, Theoretical and Concept Innovations In Digital Domains. Massachusetts: MIT Press, 2002.

[5] D. Austerberry. Digital Asset Management, Oxford: Focal Press, 2004.

[6] E.M. Rogers. Diffusion of Innovations, $3^{\text {rd }}$ ed., New York: The Free Press, 1983.

[7] Radioworld. Covergence opportunity or dead end. Retrieved from: https://www.radioworld.com/tech-and-gear/convergence-opportunity-or-dead-end. 2019.

[8] J.W. Creswell. Research Design. Pendekatan Kualitatif, Kuantitatif, dan Mixed, Yogyakarta: Pustaka Pelajar, 2012.

[9] N.K. Denzin, Y.S. Lincoln. Handbook of Qualitative Research, Yogyakarta: Pustaka Pelajar, 2009.

[10] Interviews with the commissioner and supervisor - Mr. Mohamad Sukarna, on Thursday, August 22 $2^{\text {nd }}, 2019$ at Bravos Digital Radio Studio.

[11] Radio Bravos. Retrieved from https://web.facebook.com/pg/radiobravos/community/ internal, 2019.

[12] Radio Bravos. Retrieved from: https://youtube.com/channel/, 2019.

[13] Radio Bravos. Retrieved from: https://twitter.com/bravosradio?lang=en., 2019.

[14] Radio Bravos. Retrieved from: https://www.instagram.com/bravos.radio/?hl=en, 2019.

[15] J. Tacchi. The Need for Radio Theory in The Digital Age, International Journal of Cultural Studies, 2010, No. 3:289, DOI: 10.1177/136787790000300217, 2010. 